\title{
Archipel
}

ARCHIPEL Études interdisciplinaires sur le monde insulindien

$100 \mid 2020$

Varia

\section{Theory vs. Philology in the Study of Balinese Culture, Religion, and Ritual}

\section{Andrea Acri}

\section{(2) OpenEdition \\ 1 Journals}

\section{Electronic version}

URL: http://journals.openedition.org/archipel/2141

DOI: 10.4000/archipel.2141

ISSN: 2104-3655

\section{Publisher}

Association Archipel

\section{Printed version}

Date of publication: 15 December 2020

Number of pages: 199-216

ISBN: 978-2-910513-84-9

ISSN: 0044-8613

\section{Electronic reference}

Andrea Acri, «Theory vs. Philology in the Study of Balinese Culture, Religion, and Ritual », Archipel [Online], 100 | 2020, Online since 28 November 2020, connection on 09 December 2020. URL : http:// journals.openedition.org/archipel/2141; DOI : https://doi.org/10.4000/archipel.2141 


\title{
LECTURE CRITIQUE ET ÉTAT DE LA QUESTION
}

\author{
ANDREA ACRI ${ }^{1}$ \\ Theory vs. Philology in the Study of Balinese Culture, \\ Religion, and Ritual
}

More than Words: Transforming Script, Agency, and Collective Life in Bali. Richard Fox

Cornell University Press, 2018. xviii + 239 pp., ISBN13/ 9781501725357, ISBN10/ 1501725351

This review essay is devoted to the latest book by Richard Fox on the fascinating and little-investigated subject of non-textual uses of letters (aksara) in contemporary Bali. ${ }^{2}$ It takes this wide-ranging publication as a point of departure for contributing to the ongoing debate between the "theorists" and the "philologists" in the wider disciplinary framework of Area Studies. This debate, in fact, hardly exists in the field of (Old) Javanese and Balinese studies, notably because no philologist has hitherto replied to the critique of the discipline that has been advanced over the past decade or so by theorists-Fox being the most prolific and representative of them. Taking up this desideratum, my critique inevitably reflects my own scholarly background and methodology, namely the study of the religious history of Java and Bali from a textual and comparative perspective.

1. École Pratique des Hautes Études (EPHE, PSL University, Paris).

2. I wish to thank the editorial board of Archipel for having accepted this review article in spite of the fact that a review of the same publication (van der Meij 2020) has already appeared in the previous issue of this journal. 
As its evocative title suggests, the book explores "through a study of Balinese script as employed in rites of healing, sorcery, and self-defense [...] the aims and desires embodied in the production and use of palm-leaf manuscripts, amulets, and other inscribed objects" (p. 2). Containing research carried out in the framework of the collaborative research project "Material Text Cultures" at Heidelberg University, ${ }^{3}$ the book under review alternates ethnographic case studies (mostly drawn from the anonymous Balinese village community fictively referred to as "Batan Nangka") with theoretical reflections. It is, therefore, much more than a book on aksaras from the perspective of anthropology, reflecting as it does the author's longstanding interest in the study of religion, media, and philosophy in the context of contemporary Bali and Indonesia. ${ }^{4}$

The book consists in eight chapters, earlier versions of two of which (chapters two and three) were previously published elsewhere. As the author remarks, each chapter "may be approached as a (more or less) self-contained exploration of script and writing, as taken in from a particular vantage" (p. 23 ). The first chapter sets the stage by providing a concise introduction and voicing some key points and questions, intermixed with ethnographic casesfor instance, Prof. I Gusti Ngurah Bagus' inaugural lecture in Anthropology at Udayana University in 1980 on the letters of the Balinese syllabary as a point of departure to unravel local understandings of aksaras alongside the imperatives of state bureaucracy. Chapter two revolves around the themes of religious and cultural complexity, presenting aksaras and Balinese "ways of life." Chapter three, having discussed what "life" means in the Balinese context, presents some immanent examples of usages of aksaras. Chapter four focuses on theories of practice generally and the Caru Rși Gana ritual specifically; according to Fox, this ritual reflects not only a degree of complexity, but also a wide array of seemingly contradictory purposes. Chapter five continues the discussion of the idea of practice, closely reviewing the theories of Bourdieu and MacIntyre and applying them to the Balinese context, as well as proposing to approach the Caru Rși Gana as one of the regular activities "that make up the practice of maintaining a houseyard." Chapter six critiques the idea of "tradition" as set forward by both Western and Balinese scholarly (and non-scholarly) circles, presenting the case study of Ida Wayan Oka Granoka's Grebeg Aksara ceremony and his wider project of re-orienting Balinese tradition. Chapter seven deals with translation (for instance, of such polysemic Sanskritic Balinese terms as atma or suci) and the inevitable reification entailed by the terminology used in scientific writing. Chapter eight recapitulates each preceding chapter, elaborates on a critique

3. A thematically linked edited volume stemming from the same project is Hornbacher and Fox 2016.

4. See Fox 2011. 
of Sheldon Pollock's Sanskrit Cosmopolis ${ }^{5}$ and his definition of philology as "making sense of texts," and concludes with "a few unresolved issues."

The author captivates the reader with his elegant (yet at times rather abstruse) prose, and puts forward several fascinating questions. He must be credited with an excellent command of Balinese language and its nuances (which is a rare quality among ethnographers of Bali), an expert first-hand knowledge of the island's culture and society, as well as an impressive intellectual prowess coupled with a solid grounding in modern Western philosophical theory. Containing a mix of evocative ethnographic accounts and sophisticated theoretical analyses, the book constitutes a well-crafted piece of scholarly work dealing with a fascinating and little studied subject, and certainly qualifies as a valuable resource for students of Bali and Southeast Asianists in general.

Having duly acknowledged the book's merits and the author's qualifications, I will devote the remainder of this review essay to a critical discussion of some aspects of the book that I have found to be problematic.

First, as an academic practicing a more "traditional" type of scholarship, I have found the dominance of theory over empirical data to be a distracting factor, as well as the markedly deconstructivist approach to be at times extreme. ${ }^{6}$ My reading of the book has left me with the impression that aksaras have been virtually taken by Fox as a pretext to embark on theoretical discussions. Thus, the book primarily reflects the author's concern to push his deconstructivist theoretical agenda, and only secondarily makes "a positive contribution to the scholarship on religious uses of script in Indonesia and the wider Malay region" (p. 2). As Fox admits, while the "argument is presented with detailed attention to the materials from Bali," the "examples have been chosen for their pertinence to problems of broader import" (ibid.), his ethnographic approach to Balinese uses of script being mainly "directed by a set of broader theoretical questions around the nature of communication, agency and practice" (p. 7). This may be a reasonable compromise, but some readers might find it to be a deterrent.

Undeniably, the ways in which aksaras are (and were) used in Bali constitute an extensive subject; recognizing that the vastness and complexity of the material is such that it is impossible to provide an exhaustive account of the subject, Fox "picks up where [...] others have left off, to reflect further on Balinese uses of script and writing" (p. 7). While this is a fair description of the essence of the book, Fox appears not to have always meaningfully (and, sometimes, fairly) engaged with the work of his predecessors-especially

\section{Pollock 2006.}

6. A case in point is Fox's critical remark that to understand "practice" as "what people do" would entail "ethnocentric presuppositions smuggled in under cover of common sense," unduly naturalizing "people" as "agents," and opposing "practice" to "theory" (n1, p. 197; cf. p. 81) — as if those concepts did not exist in the Balinese intellectual framework, both historically and nowadays (which they actually do). 
philologists. For instance, Fox occasionally refers to a handful of pertinent secondary sources, ${ }^{7}$ but draws hardly any data from them, in spite of claiming to apply anthropological thinking to philology and codicology in order to "unsettle received understandings of textuality and writing as they pertain to the religious traditions of Southeast Asia" (p. 2). This body of work on aksaras discusses relevant primary sources that could have been brought into a fruitful conversation with the ethnographic research carried out by the author.

The lack of real engagement with philology, as well as Old Javanese texts, constitutes one of the most problematic aspects of the book indeed. Fox rarely misses the chance to offer critical remarks towards philology in general, and Old Javanese philology in particular; yet, he often presents a caricatural characterization of them. For example, Fox affirms that, with some notable exceptions, scholars have tended to devalue the material, nonliterary aspects of writing in favor of a "more conventional model of 'the text' understood as a medium for the transmission of religious ideals and ideas" (p. 1); yet, while admitting that Balinese apotropaic writing not only challenges but also coexists with the notion of script as a neutral medium for the transmission of textual meanings (p. 2), he neither acknowledges the existence, nor makes use, of relevant textual material and social contexts that do not conform to his analysis - that is, Old Javanese texts that transmit abstract metaphysical ideas, and social contexts showing little if any concerns with the ritual or "magical" dimensions of texts/artifacts. This is a pity, as Fox's fresh perspective to apply anthropological thinking to philology could have offered a much needed corrective to the general disregard paid by most (Western) anthropologists to texts and literacy in Bali, to the extent that Balinese civilization has been treated as if it were pre-literate in spite of the fact that written texts (whether or not transmitted through traditional media, i.e. lontar palm-leaf manuscripts) are perceived as ultimately authoritative sources of knowledge, and still form an important dimension of the life of Balinese agents in various social contexts.

By emphasizing the non-textual dimension and failing to engage with other complementary aspects, Fox ends up reinforcing the stereotype that what he calls "philological readings" or a "focus on textuality" is an Euro-Western phenomenon, as opposed to a Balinese natural propensity, as it were, for nontextual uses of writing and inscribed media. This contrast between Western philological and Balinese sensibilities seems artificial, ignoring as it does that many Balinese practices in fact derive from Indic precedents: as Fox himself admits, drawing on the work of Pollock, there is a "happy congruence between modern philology and many of the South Asian commentarial practices that it has taken as its object" (p. 181). Since the same can be said of the Indiaderived Balinese practices, it is quite ironic that Fox unreflectively applies a Western theoretical paradigm inspired by the critique of sexuality by Foucault

7. For instance, Rubinstein 2000; Hunter 2016; Acri 2016. 
when, intending to do away with a foundational conception of textuality in Bali, he asks whether the (Western) "idea of 'the text' and 'its manuscript' obfuscates the very practices that generated these inscribed objects in the first place" (p. 19). But one could point at the similarities existing between philology and Balinese textual practices, in the spirit of the (de-Orientalizing) "global philology" intellectual project undertaken by Pollock and others. I for one think that philology — and not Western theoretical analysis or the deconstructionist agenda - forms the "middle ground" in which the encounter between the Western and Balinese paradigms can happen.

Fox embarks on a critique of Pollock's Sanskrit Cosmopolis on the ground that, philology being understood as "the discipline of making sense of texts, there is some question as to whether this approach is suitable for thinking about nonliterary uses of writing" (p. 9). Fox's application of the "language ecology" framework in chapter two seems promising indeed; however, his denial of the role of philology, as well as of the transregional interplay between Sanskrit language and culture and their vernacular counterparts in the premodern Indic world, to understand non-textual uses of writing in Bali can be countered by pointing out that the religious (as well as material) cultures of many Southeast Asian societies have been influenced by the textual funds of transregional Indic religious traditions. When approaching the "magical," non-textual uses of script, we cannot avoid confronting ourselves with the constellation of ideas and practices derived from prescriptive texts that set an historical precedent. ${ }^{8}$ Fox's prejudice against a narrowly conceived philology hardly does justice to the complex dynamics that have contributed to shape Balinese ideas and practices both historically and at present, and leaves us with many unanswered questions. Asking one such questions, namely "whether these 'texts' were always meant to be read - that is, whether it was their textuality, so construed, that mattered the most in the assemblage and use of these inscribed objects," Fox attributes to Pollock and his followers a propensity for "naturalizing a philological orientation to writing," glossing over "philologically noncompliant uses of script and writing," and obscuring "a range of equally important uses of writing on the subcontinent and beyond" (p. 181), such as amulets and other forms of script magic throughout Southeast Asia. Fox may be blamed in his turn for glossing over the textual material and related practices that are not strictly compliant with his views, thus unduly naturalizing non-textual usages of script.

As stressed by Fox, Balinese script undeniably has many lives beyond the purely "textual" dimension. However, the author's lack of historical analysis has seemingly prevented him from asking, and elaborating on, the relevant question as to whether these lives are continuities or rather revivals. Fox thinks that recent conceptions of writing as a neutral medium for the transmission of

\footnotetext{
8. See Acri 2016.
} 
textual meaning are linked to academic philology, reformed Hinduism, and local politics, as opposed to "traditional" practices of apotropaic writing and other non-textual uses of script. While this is often the case, there is room to hypothesize that, in some cases, the other way around may be true. Recent research, as well as my own observations in the field over the past twenty years, suggest that the ritualization of literacy linked to manuscripts, as well as the focus on textual performance that we can witness in contemporary Bali, ${ }^{9}$ reflect a recent trend associated with the rise of movements affirming Balinese identity and the widespread introduction of new media - an emblematic case of "invented tradition." Furthermore, in both Java and Bali, it is in the contexts where book-manuscripts are no longer used as "books" or textual media, that is, when their scripts and languages are no longer understood and actively used by a community of readers, that these objects become more prone to being sacralized and associated with magical or ritual uses. This is the case, for example, of pre-18th century Indic palm-leaf manuscripts in contemporary Java, even in Islamic contexts. Similar dynamics are at play in contemporary Bali-where, one should keep it in mind, very few people can read kawi script, let alone understand the language, and where a divide at the elite level between "traditionalists" and "modernists" appears to exist. Many specialists of Balinese manuscripts, including competent Śaiva priests (pedanda siwa), but also lay intellectuals and men of letters trained in both "traditional" and academic settings, regard palm-leaf manuscripts as media primarily intended to be read and reproduced for the knowledge they contain rather than ritual objects to be worshiped or used for magical purposes - not the least because many texts have little to do with religion, ritual, or magic, being rather appreciated mainly for their poetic, literary, or narrative qualities, or as sources of legal or otherwise practical knowledge. These objects are often handled, stored, and guarded with great care, but not necessarily used as talismans or ritual paraphernalia, let alone considered "living entities." Thus, to see magic and efficacy everywhere would be unwarranted. Furthermore, pace Fox (p. 5), aksaras are not powerful and sacred per se, but only when they are written or pronounced as mantras in particular sequences or configurations, e.g. provided with nasalizations and manipulated mentally or visually during meditative practices. Regrettably, taking for granted the (still limited) work by previous scholars on the subject, as well as the reader's previous knowledge, the book remains silent about the "inner workings" of the science of aksaras in connection with psychophysical practices, and provides hardly any concrete examples of configurations of scripts, diagrams, etc. ${ }^{10}$

9. On which see, for example, Creese 2014; Darma Putra 2014.

10. For instance, in table 4.1 (p. 87) the Śaiva syllables Sa Ba Ta A I, which are central in Balinese speculation and ritual practice, are neither explained nor contextualized. 
An aspect of Fox's book that I find somewhat baffling is the author's general characterization of Balinese culture and ritual praxis as a chaotic, incoherent, and often-contradictory complexity that cannot be reduced to any underlying system. ${ }^{11}$ Whenever he has a chance, Fox offers a critique of the notion that contemporary ideas and practices would be informed by a (more or less coherent) cultural system carried forward by the Old Javanese and Balinese literature that has been preserved and produced on the island since the premodern period. For instance, he questions "the idea that day-to-day practices are simply an instantiation of an underlying philosophy (e.g., as explicated in one or another tutur manuscript)" (n7, p. 184); having expressed his puzzlement at the Caru Rși Gaṇa's ritual "seemingly incongruous juxtaposition of battle, exchange, transformation, and cleansing," he elaborates his idea of Balinese ritual representing a set of "multiple incongruities," and further speculates that "one might be inclined to think that Balinese were similarly adrift when it came to the purposes animating their religious rites" (pp. 119-20). He goes so far as to affirm that, although it would not be impossible to "formulate a consistent interpretation [...], doing so would introduce a form of coherence recognized neither by the ritual manuals nor by those performing the rites" (p. 101); and that "one can certainly imagine an overarching conceptual framework that would render these ideals compatible with one another. And yet, as we saw, this would introduce a degree of coherence that was not only absent from the commentaries themselves but also resisted by many of those who followed them" (p. 103). The above statements reveal the fallacy of confusing expert and non-expert views: taking his informants at face value and avoiding to dig deeper when they direct him to those who know the doctrines written in the texts, ${ }^{12}$ Fox seemingly ignores or downplays the specialization of work

11. Witness, for instance, the idea that "the common translation of atma-as 'soul,' 'spirit,' or 'self' - and the way that it has been attributed to Balinese as part of a 'cultural schema' or 'religious worldview' obscure both the complexity and potential for ambiguity that are characteristic of day-to-day life on the island" (p. 165); the statement that "Balinese tradition probably never had the sort of 'coherence' that is presupposed in prevailing accounts of translation - though I would be quick to add that I doubt if any other tradition ever did either" (p. 169); the existence of "[p]luralities of conflicting anthropologies within what is ostensibly a single cultural milieu," which would argue against the "stability and systematicity of the "cultural schemes" that are presupposed in prevailing accounts of translation" (pp. 170-71).

12. The explanation given by the informants, i.e. "that's just how it is," is particularly telling in this respect. The agents' self-admitted ignorance of the purpose of the offerings is not surprising, for they are not the ones in charge of, and entitled to, knowing the meaning - only the high priests, the recipients of the esoteric doctrines, are. Further, I do not agree with Fox's idea that the understanding of offerings (caru) as nyomya (from somya, "benign") or "cleansing" "appears to be a relatively recent conception" in Bali (p. 94), for, as Fox himself concedes, "it plays on an older notion of transforming coarse and often malevolent forces into their more refined counterparts" 
characterizing Balinese ritual, which involves multiple agents, from the "workforce" to those who "know the meaning." Furthermore, having failed to grasp the underlying coherence of the system of Balinese ritual, he concludes that it has little if any coherence on the one hand, and unwarrantedly takes for granted the non-systematic, non-intellectual, and fragmentary character of the texts on the other, accepting the received idea that they constitute place-andperson-specific documents. ${ }^{13}$ While Fox blames philology for unreflectively imposing Western categories on the Balinese, to give up the very possibility to understand the "others" by depriving them of a coherent and resilient cultural heritage providing the mental framework through which the world is organized strikes me as a no less subliminally ethnocentric and exoticizing perspective. The abandonment of the endeavor of actually reading and interpreting the texts (something that many Balinese have luckily continued to do for the past several hundred years) on the one hand, and the rejection of historical investigation on the ideological grounds of the postmodernist/deconstructivist theoretical paradigm on the other, carries the inevitable disadvantage, as David White aptly puts it, of inhibiting "any opening to the other whatsoever." 14 My conviction is that no amount of critical self-reflectivity can resolve this fundamental impasse.

Throughout the book, Fox portrays Balinese religious culture as being dominated by a distinction between state-bureaucratic representations of "Hindu religion" (Agama Hindu), "characterized by a moralizing monotheism that aspires to the universal status of world religion," and "the innumerable rites and related activities that permeate day-to-day life on the island [...] often inextricably tied to a particular locale, incorporating aims and ideals that anthropologists and other regional specialists have more commonly associated with the less rigorously institutionalized activities of healing, sorcery, and selffortification" (p. xiii). While this characterization is per se not incorrect, this strictly dichotomous order does not take into account other textual genres and social milieus that could make the picture more complex and multifariousfor instance, the genre of philosophical and theological texts called tattvas, or the most esoteric-minded among the pedanda siwa. Fox questions the

(ibid.). Calling this "a series of tropes that were not self-evidently compatible," Fox asks whether there is "a narrative account that might pull them together into a cohesive whole" (p. 96); then, having reported the results of his interview with a pedanda, struggles to find a plausible explanation for "the ideals of cleanliness and purification, [...] which do not seem so readily assimilable to the aims of buy-off and protection" (p. 99). The ideals of purification, transformation into a benevolent form, and chasing away, are actually quite clearly reflected in the Old Javanese texts: see Acri and Stephen 2018.

13. For a critique of this idea, elaborated in previous anthropological literature, see Acri 2011.

14. See White 2005: 3 . 
historical existence of a canon, and attributes the idea of a "text" transcending the bounds of matter and its physical presence to the advent of the modern (i.e. Western-influenced), reformed version of Balinese Hinduism, which would stand in contrast with older ideas of script and writing (p. 48). This does not seem to be the case, for there are reasons to believe that premodern authors and scribes could differentiate between a text as an abstract entity and a text in its immanent instantiation (i.e. a given manuscript) $;{ }^{15}$ furthermore, as I have argued in previous publications, there existed a shared, transregional body of systematic texts expounding both India-derived Śaiva doctrine and internalized yogic practice in Java and Bali. ${ }^{16}$ This body of texts took a life of its own in Bali from the Majapahit period onwards. I can see very little if anything in them in terms of expressing local contingencies or referring to realia, ritual practices, or social agents. In fact, they come perilously close to the Western "philological" conceptions of textuality critiqued by Fox.

A concrete example of the perspective critiqued above is provided by Fox's discussion of the ritual of the Caru Rși Gana. Having advanced a few questions relating to the explanation of various actions and stages of the ritual, such as the final noise-making, Fox notes that an answer could be attempted by looking at the Balinese palm leaf manuscripts containing texts with ties to Javanese and South Asian Indic heritage, as well as the "evidence of Indic precedent in the form of rites employing similar paraphernalia, procedures, and terminology," and that "[s]uch recourse to textual precedent has figured prominently in the scholarship on Balinese religion and culture, as this often appears to provide a degree of certainty and order that has otherwise proven elusive" (p. 93). After a digression on a conversation with a Balinese priest that highlighted tropes that are not self evidently compatible, Fox returns to the issue by examining the text Bama Kertih (pp. 99-100), which according to him "offers neither theological interpretation nor additional information," and can be read as notes for a performance, which are relevant only for the ritual utility and specific circumstances (p. 100). While these eminently practical texts do exist, and form a not insignificant portion of the extant corpus, one cannot ignore the existence of other texts specializing in theology, i.e. tattvas (and, to a lesser extent, tuturs). To look for theological interpretations in the former genre of texts would be like looking for theological discussions in a Holy Mass guide, then, having found none, concluding that Catholicism possesses neither theological texts nor a proper theology. We should not

15. This distinction corresponds to what Tanselle (1989: 69-70) called "text of work" and "text of document" - the former implying something pre-existing. The very act of extracting and recopying a text from a manuscript, or creating compilations out of different parts of different texts, as it often happened in Bali, presupposes an understanding of the difference between the "text of work" and the "text of document." 16. Acri 2011. 
forget that Balinese religion - and especially its theological and philosophical foundational core - was until the mid-50s an initiatory, highly esoteric tradition (and still remains so among the traditionalist pedandas), possessing a fragmentary textual canon as well as a body of knowledge and practices transmitted orally. Very few encyclopedic works have survived to the present, and what we have is a vast array of texts specialized in various domains, so one has to read a significant sample of the whole corpus to get an idea of the system informing its theology and ritual life. Similarly, different agents (viz. pedandas, pemangkus, resi bhujanggas, balians, commoners, etc.), using different genres of texts, reflect various know-hows and specializations. As a philologist, I feel that rather than regarding Balinese ritual as "a multiplicity of apparently incongruous aims and ideals" (pp. 101, 103) to be approached in terms of "practice" or "practice theory," an outstanding desideratum to fulfill would be the documentation (through philology) of this body of material and its interpretation in the light of the premodern religious paradigm reconstructed from relevant texts from Bali, Java, and their Indian prototypes. The texts would then be studied by anthropologists to see how they are read and performed in various contemporary Balinese social milieus, or if they reflect any living Balinese realities. ${ }^{17}$ Rather, Fox's main concern is to demolish "philological" notions of textuality, in spite of the fact that, he admits,

philological analysis is well suited to answering certain kinds of questions. Its findings are historical in their own way; and, when it comes to accounting for events on the contemporary scene, the textual record may have much to contribute to our understanding of the emergence and relative stability of certain ideas and styles of reasoning. [...] there are important literary parallels for many of the uses and acts of aksara that I found in Batang Nangka, but the question of how contemporary practices are related to accounts found in palm-leaf manuscripts is just that - a question. (p. 78)

Without taking upon himself the onus of supporting his claim, Fox simply affirms that texts do not bear much relevance to everyday life, and also that, there being no unified "scriptural culture" or literary community, any regularity in opinion must be attributed to the sedimentation of practices of social organization and collective labour (p. 57). It is quite true that in Bali there are competing ideals of agency, community, and the common good, but there also exists a mosaic of scriptural cultures and communities, and several categories of expert/ literate agents. It seems to me that the specialized know-how of (competent and Old Javanese-literate) pedandas is engaged to an insufficient extent in the book - unless when the priests' statements serve the purpose of confirming Fox's (pre)conceptions about a supposed incoherence of Balinese ritual, not to mention the texts themselves - except one or two fragmentary manuals or

17. A preliminary attempt, focusing on the Balinese offerings called bhütayadnyas, is Acri and Stephen 2018. 
practical aide-memoires intended to provide guidance for low-level temple ritualists. If anything, philology can still be useful to understand "how and why we got here." Texts do not represent "fixed points" (pp. 124-25), unchanged and immutable; the task of philology is not to isolate them (which would amount to a sterile antiquarianism), but rather to provide relevant material for scholars, including anthropologists, who could investigate how the community has related itself to, and reused, these media from the past. The romanticized and essentialized vision of Balinese past as static, which Fox rightly problematizes, does not warrant us to abandon a text-historical endeavor, for Old Javanese literature has survived for hundreds of years at the hands of elite and non-elite specialists who have translated it into a significant aspect of Balinese life-in ways that are both textual and non-textual.

The reduction of the analysis to two parallel sets of relations, i.e. a local/ embedded and materially immanent theory of writing and power on the one hand, and a "displaced and dematerializing theory of writing linked to translocal forms of solidarity associated with the postcolonial nation-state" (p. 48) on the other, misses an important historical and translocal dimension, namely the filiation of Balinese religion and ritual culture from Śaiva religiosity and ritual praxis - Bali being a piece in the mosaic of vernacular cultures that were in conversation with Indic cultural elements across the Sanskrit Cosmopolis. This transregional and comparative historical perspective is missing in the book. To be fair, the author devotes one and a half pages to "regional resonance" (pp. 8-9), admitting that there is reasonable scope for comparison with the wider scholarship on religion in Southeast Asia and beyond, yet concomitantly criticizing Pollock's philological approach within the framework of the Sanskrit Cosmopolis as being not suitable for thinking about nonliterary uses of writing. But this gesture is not enough to bring the non-Balinese materials into a meaningful conversation with the "textual" and ethnographic cases discussed in the book, in order to detect possible historical filiations and local variations.

This lack of historical and comparative perspective is not surprising given Fox's programmatic refusal to accept such reified and totalizing concepts as "tradition" (such as the "unifying" translocal Indic religious traditions, "tantric traditions," and "Hindu-Buddhist traditions," p. 124), textual or historical precedent, as well as his anti-cosmopolitan stance. The last is perhaps the logical corollary to Fox's conception of heterogeneity, incoherence, and chaos as essential features of Balinese culture and religion, which reinforces the perception of the same as exotic and unique phenomena-reflecting some sort of Balinese "exceptionalism"- that can only be studied in their own terms rather than as a part of wider cultural flows of ideas and practices across southern Asia. In his deconstructivist endeavour, Fox affirms that "[s]tudents of Southeast Asia have long recognized that unifying terms such as Hinduism, Buddhism, Tantrism, and animism do not adequately reflect the heterogeneity 
of the region's history and culture" (p. 79). Without naming these students, Fox labels these terms uncritical and oversimplifying; concomitantly, he does not acknowledge or unpack the indebtedness of these Balinese ideas and practices about language and script to Indian prototypes, in spite of the fact that most of the usages of aksaras that he describes are apparently derived from the medieval South Asian religious traditions, more specifically notions and practices of purity and power current in Śaiva and Buddhist tantric paradigms across medieval South and Southeast Asia, as well as parts of Central and East Asia. Fox briefly mentions only the comparative potential of Mainland Southeast Asia in the Pāli Buddhist milieus of Thailand, Cambodia and Myanmar, ${ }^{18}$ or the affinities with Southeast Asian's Islamic traditions, or again Indic, Persian, and middle eastern contexts, overlooking what are to my mind more directly pertinent prototypical instances from Indic tantric traditions. A discussion of the literature on yantras, or the Buddhist (i.e. Mahāyāna and Vajrayāna) and Śaiva "cult of the book," ${ }^{19}$ or again the Śaiva script-mysticism from India and Bali $^{20}$ would have contributed important elements to the discussion.

This programmatic erasure of historical and textual precedents, based on the critique of "a certain commonsensical understanding of the-past-in-thepresent that is grounded in essentializing metaphors of cultural influence and the transmission of ideas" (p. 122), as well as of the concept of "tradition," 21 makes it difficult to do justice to Balinese complexity. It is quite clear that the phenomenon of script in Bali was shaped by historical dynamics that cannot be adequately appreciated uniquely from the perspective of Balinese ethnography, which has often limited the documentation and analysis to the level of interviews, and accepted at face value the (non-expert) informants' reports to build a theory of Balinese culture without investigating both Old Javanese texts and the specialized human custodians of the esoteric traditions they carry as the ultimate sources of knowledge. Fox's book is no exception - a case in point is the vague explanation of the ritual of inscribing letters onto the body provided by the invitees to a wedding as having

18. Where the magical usages of scripts are, according to him, treated as non-Buddhist cultural accretions or popular superstition (but contrast the studies by Bizot, ascribing them to a tantric fund: see Crosby 2000). More pertinent, insofar that they are indebted to translocal Tantra (which Fox does not mention), are the comparisons that Fox admits may be drawn with Buddhist yantras used by weizzā practitioners (n36, pp. 195-96).

19. On which see De Simini 2016.

20. Hunter 2016; Acri 2016.

21. And yet, contrast what seems to be an apt defense of such a laden word: "we need tradition, or something like it, if we hope to render other people's practices intelligible as reasonable human action. For novel utterances and actions can only be said to 'make sense' insofar as they may be interpreted with reference to the precedent set by one or more prior acts" (pp. 122-23). 
"something to do with purifying (B. nyuciang) the newlywed" (p. 36). Pace his claim that "establishing provenance for a given practice may prove more problematic than it appears, and this for reasons that are at once evidentiary and theoretical" (p. 9), a comparison with Indian traditions (both premodern/ textual and living) would reveal close parallels with the tantric notions and praxis of purifying the body through akșaras called bhütaśuddhi. ${ }^{22}$ The same could be said with respect to the "holy numbers" (recurring in Balinese ritual, architecture, etc.) that amount to a "sacred geometry" found also in India and in other Indic contexts (for instance, ancient Javanese sacred architecture), which rests on the edifice of Śaiva ontology and cosmology revolving around a set of correspondences between micro- and macro-cosmos. Similarly, the Balinese concept of "a life force in buildings" (p. 45), suggested to Fox by the fact that one of the functions of amulets is to "animate" (ngidupang), and that the expression maurip "alive" is associated with some elements of the ritual offerings (p. 43), ${ }^{23}$ may reflect not just a form of "new animism" (n41, p. 196) but older (both Indian and Javanese-Balinese) Śaiva concepts of micro-macrocosmos, emanation of the universe from the paramount deity, and the concept of an universal consciousness (cetana) abiding in every living and non-living entity, trapped in materiality (acetana) and prone to disaggregation. Fox, noting how aksaras are related to every level of reality, claims that scholarly literature has reproduced lists of links among letters and colours, directions, deities, etc. in broadly Indic traditions of South and Southeast Asia, yet "it has offered comparatively little insight into the rationale for elaborating such complex systems of associations" (n28, p. 195). This is not the case, for the systematics of such associations can be easily traced back to tantric Śaiva ontology, cosmology, and subtle physiology. Yet Fox approaches the matter by looking "at the procedures in which these series are employed and the purposes they are meant to serve" (ibid.), thus stopping at the first level of analysis and the immanent aspect of the phenomenon without undertaking any comparative and historical endeavor, and thereby remaining comfortably within the boundaries of Western theory-namely, which Western thinker could provide us with the key to "make sense" of these ideas and acts. Along similar lines, the "typically Balinese" way of thinking and argumentation through associations, neologism, and homophony that is embodied in reading clubs (mabasan), among many other instances of Balinese cultural life, does

\section{Acri 2016.}

23. Fox translates the expression winangun urip (referred to a duck or chicken at the center of the offering) as "splayed out as if alive" (p. 86). This is an appropriate translation, however it does not take into account the rather obvious play of words, urip being a reference to the "mystical numbers" recurring in Balinese architecture, ritual, and theology, and the alternative meaning of the passive verb winangun "to be built" (see n21, p. 199, where he refers in the same context to offerings "laid out in accordance with the urip (life[?]) numbers associated with the compass directions"). 
not represent the virtuosity of one brilliant yet highly idiosyncratic thinker (i.e. Granoka) whose rhetoric style overflows with "terminological superfluity," but a central and resilient feature of Balinese culture, which apparently has much in common with the Sanskritic practice of nirvacana or semantic analysis (sometimes depreciatively referred to as "folk etymology"). Fox's (p. 150) invocation of Sweeney's theory of "residual orality" in the Malay cultural context to explain this Balinese cultural feature does not hit the mark, failing as it does to do justice to Balinese hermeneutical practices and their indebtedness to Old Javanese textuality. ${ }^{24}$ Even worse, it seems to me that it subliminally falls into the trap of exoticism, assuming as it does a quintessential opposition between Western (and Indic) literacy vs. Southeast Asian orality-whereas Bali has, in fact, one of the highest number of manuscripts per capita in the Indic world. To resume: the above examples illustrate that the obliteration of the importance of Indic religious and textual traditions, and (Śaiva) Tantra in particular, in Bali as the driving force that has shaped much of the premodern and modern paradigm, may be regarded as "the elephant in the room."

A final point of criticism I would like to raise is that the author often seems to take a sort of "higher moral ground" when criticizing philology. For instance, he denounces a disjuncture between philological enquiry and the practices of composition, copying, and performing that generated its object of study (p. 78), but in spite of his efforts to practice a self-reflecting and dialogic anthropology he does not sufficiently stress that ethnography, Euro-American academic writing, or any discipline based on the Western scientific paradigm indeed (including postmodern theory/deconstructivism itself) carry the same disjuncture. ${ }^{25}$ Fox, subscribing to Rubinstein's view that "kekawin philology as practiced to date undermines the religious beliefs and values upon which kekawin composition has been based," states that "[i]f this were really so, it may be worth reflecting a little more carefully on the foundations of our work and its consequences - both intended and otherwise" (p. 78). This call for selfreflectivity is certainly legitimate, however it remains a gesture as no concrete steps are taken to follow it through. ${ }^{26}$ I cannot agree more on the statement

24. This is, in fact, implied in Fox's brief characterization of the "totalizing amalgamation" reflected by the ritual-performance of the Grebeg Aksara staged by Granoka as featuring "various forms of repetition, word play, and other elements characteristic of older practices of 'text-building' in Java and Bali" (p. 149).

25. As McGrane put it, "[a]nthropology lives by seeing and interpreting everything as culture-bound [...] everything but itself" (quoted in Hobart 1996: 4).

26. For instance, Fox asks whether Balinese ideas of power and efficacy are "additive to an underlying textual essence that may be extracted for purposes of philological analysis and translation," and whether "this reductive presumption to scientificity [would] obscure ontological and epistemological commitments that are no less contingent, and historically peculiar, than their Balinese counterparts" (p. 23), to which I would reply that the author's work is no less prone to falling into the same trap. 
that "despite protestations to the contrary, it seems the day-to-day practices of critical enquiry all too often exempt themselves from the 'theory of practice' they intend to foist on Others" (p. 52) - Fox's own work is no exception. Similar considerations apply to his statement - intended to critique such entrenched Western assumptions as an instrumentalized conception of writing, the nature of language and text, etc. - that "indeed it is only by virtue of an unexamined presumption to superior comprehension that these analytical procedures may continue to be 'applied' transitively to other people's practices, as if from a place apart" (p. 182). ${ }^{27}$

Perhaps the answer to Fox's question as to whether cultural analysis is "ultimately incapable of escaping the strictures of an objectifying scientism" (p. 122) is bound to be a "no." Unless we gave up the Western pretension to a "higher" scientific truth and enact a "cognitive shift" so as to embrace the metaphysics, cosmology, and conceptions of magical efficacy that give meaning to the Balinese worldview and agency, any call for self-reflectivity amount to mere (and ultimately useless) gestures. Unless this is done (assuming it can be done indeed, which is a huge question mark), no claims can be made of any scholarly methodology or theoretical approach-including those aiming at deconstructing and problematizing Western intellectual and disciplinary paradigms - to being less removed from Balinese sensibilities. An ethnographic account, based on observation and interviews, of the practices of living subjects relating to the universe of Balinese "magic" in an academic book, as well as the theorizing about them, is no less an act of "epistemic violence" than a critical edition of a text. Similarly, to approach Balinese complexity (at the micro- and macro-ethnographic level) uniquely in the light of its social and cognitive dimensions shaped by dynamics of power, i.e. through an "analysis of rival styles of practical reasoning" drawn from MacIntyre (p. 79), seems reductionist to me, and quite removed from the Balinese sensibilities that the author tries to defend from the epistemic violence of philology. ${ }^{28}$ I for one think that instead of interpreting Balinese

27. On the other hand, I have appreciated Fox's honest formulation (by way of a "thought experiment") of what is there to learn by "inverting the model," i.e. "what sorts of relations sustain the "life' of scholarly writing;" "what forms of solidarity are cultivated through its networks of loosely calculated debt and repayment;" "the self-fortification achieved through peer-reviewed publication;" "the harm often deliberately effected by means of published review;" or the "apotropaic purposes served by preemptory self-criticism" (p. 182).

28. This negative stance towards philology is apparent in Fox's characterization of my contribution (Acri 2016) as "a more traditionally philological approach to the yogic 'imposition of the syllabary'," as opposed to Hornbacher's study on the "esoteric tutur literature for contemporary practices of healing and sorcery $[\ldots \mathrm{m}]$ ore closely attentive to Balinese sensibilities, and the philosophical problems engendered by traditional philology" (p. 8). 
ritual in the light of the ideas of this or that Western theoretician, or worse still dismissing it as a congeries of contradictory aims, it would be more useful to approach it in the light of the emic religious paradigm, first of all the emanationist theory of the Śaiva ontic levels (tattva) and the concept of somya. ${ }^{29}$ These concepts are either directly explained in the doctrinal texts (also, perhaps not coincidentally, referred to as tattva), or indirectly provide, and enable in the background, the philosophical frameworks on which the ritual and mythological texts rest. These cosmological and philosophical notions provide the rationale of many aspects of Balinese life, for instance the island's ritual calendar, and are also reflected in mythology and folklore, as well as the visual and performative arts. This approach might actually do justice to the Balinese way of doing things - probably more so than Fox's invocation of Collingwood to explain the five stages of Balinese rituals ( $\mathrm{p}$. 84). If we are open enough to actually pay attention to these emic paradigms we would realize that Balinese habits of thought and action, far from being unsystematic, chaotic, incoherent, heterogeneous, and non-classificatory ${ }^{30}$ in nature, reflect quite a different kind of order and complexity, i.e. a "totalizing amalgamation" (p. 149) 31 $^{31}$ or dynamic taxonomic system of classification, indeed - that has been shaped by the "fractal," "mandalic," or "cabalistic" (rather than Cartesian) mechanics characterizing many Indic cultural systems, and especially Tantra. ${ }^{32}$

Frankly speaking, I find it quite surprising that Fox does not seem to realize (or take trouble with) how theoretically-driven Western scholarship has ended up not only feeling so far removed from the realities it describes, but also perpetuating the asymmetrical "relationship between the Euro-American intellectual and local intellectuals." ${ }^{33}$ To put Chomsky's generative grammar on

29. This concept is related to the ritual performances of mürwa kāla and ruwatan in Java, and both stem from an Indic/tantric religious and ritual fund that has survived to the present in Java through partial Islamization.

30. "Despite the proliferation of taxonomy in formal representations of the island's religious and cultural traditions, in my experience Balinese habits of thought and action do not favor this style of classification" (n14, p. 198). This statement strikes me as inaccurate, as it grossly over-simplifies and over-generalizes the matter. Indeed, many central aspects of Balinese life can be conceived of as reflections of a classificatory cosmological system - a case in point being the (ultimately Śaiva) enumerations based on $9(8+1)$ and $5(4+1)$ (on which, see Basset 2010), which have also survived in present-day Java.

31. This expression is used by Fox when quoting a sentence by Clifford Geertz describing an Indonesian student's cultural framework as an "extremely complicated, almost cabalistic scheme in which the truths of physics, mathematics, politics, art, and religion are indissolubly, and to my mind indiscriminately, fused" (p. 149).

32. Insightful glimpses of this system have been offered by Basset 2010 and 2015.

33. Hobart 1996. 
equal footing with Balinese "life of letters" is a nice gesture (p. 81), but does little to help us to take the Balinese "at their word." (pp. 23, 182). If one really wants to give the Balinese a voice, solipsistically attempting to deconstruct Western categories through a Western paradigm seems of limited usefulness, and it does not automatically lead to actually understanding the (epist)emic paradigm underlying Balinese conceptions and practices. Fox asks a lot of interesting questions, but provides few concrete answers. Perhaps a more transformative type of paradigm is required by Western scholars in order to think and act like the Balinese, and translate this thinking and acting into scientific prose. In the absence of that transformation, the "middle ground" I invoked above, namely reading and trying to make sense of texts in their contexts, seems to be our best bet to elicit a fruitful encounter between Bali and the West.

\section{References}

Acri, Andrea, and Michele Stephen. 2018. "Mantras to Make Demons into Gods: Old Javanese Texts and the Balinese Bhütayajñas." Bulletin de l'École française d'Extrême-Orient 104: 143-203.

Acri, Andrea. 2011. "A new perspective for 'Balinese Hinduism' in the light of the pre-modern religious discourse. A textual-historical approach." In The Politics of Religion in Java and Bali. Syncretism, Orthodoxy, and Religious Contention, edited by Michel Picard and Rémy Madinier, pp. 143-67. London/New York: Routledge.

Acri, Andrea. 2016. "Imposition of the Syllabary (svaravyañjana-nyāsa) in the JavanoBalinese Tradition in the light of South Asian Tantric Sources." In The Materiality and Efficacy of Balinese Letters: Situating Scriptural Practices, edited by Annette Hornbacher and Richard Fox, pp. 123-65. Leiden/Boston: Brill.

Basset, Catherine. 2010. "L'univers du gamelan: opposition théorique et unicité fondamentale." Archipel 79: 125-94.

Basset, Catherine. 2015. "Musique et architecture à Java et Bali: structures cosmologiques de la consonance universelle." In Architecture et Musique: Espace-Sons-Sociétés, edited by Jean-Philippe Velu, pp. 31-78. Sampzon: Delatour France.

Creese, Helen. 2014. "The Utsawa Dharma Gita Competition: The Contemporary Evolution of Hindu Textual Singing in Indonesia." The Journal of Hindu Studies 7, no. 2: 296-322.

Crosby, Kate. 2000. "Tantric Theravāda: A Bibliographic Essay on the Writings of François Bizot and others on the Yogāvacara Tradition." Contemporary Buddhism 1, no. 2: 141-98.

Darma Putra, I Nyoman. 2014. "Popularizing Religious Values through Textual Singing on Interactive Radio and TV Programmes in Bali." The Journal of Hindu Studies 7, no. 2: 273-95.

De Simini, Florinda. 2016. Of Gods and Books: Ritual and Knowledge Transmission in the Manuscript Cultures of Premodern India. Berlin: De Gruyter.

Fox, Richard. 2011. Critical Reflections on Religion and Media in Contemporary Bali. Leiden/ Boston: Brill.

Hobart, Mark. 1996. "Ethnography as a Practice, or the Unimportance of Penguins." Europaea 2, no. 1: 3-36.

Hornbacher, Annette, and Richard Fox (eds). 2016. The Materiality and Efficacy of Balinese 
Letters: Situating Scriptural Practices. Leiden/Boston: Brill.

Hunter, M. Thomas. 2016."The Medium is the Message: Chirographic Figures in Two Traditions." In The Materiality and Efficacy of Balinese Letters: Situating Scriptural Practices, edited by Annette Hornbacher and Richard Fox, pp. 100-22. Leiden/Boston: Brill.

van der Meij, Dick. 2020. "Richard Fox, More than Words. Transforming Script, Agency, and Collective Life in Bali." Archipel 99: 293-95.

Pollock, Sheldon. 2006. The Language of the Gods in the World of Men: Sanskrit, Culture, and Power in Premodern India. Berkeley, CA: University of California Press.

Rubinstein, Raechelle. 2000. Beyond the Realm of the Senses: The Balinese Ritual of Kekawin Composition. Leiden: KITLV Press.

Tanselle, G. Thomas. 1989. A Rationale of Textual Criticism. Philadelphia: University of Pennsylvania Press.

White, G. David. 2005. "Ronald Davidson, Indian Esoteric Buddhism." Journal of the International Association of Tibetan Studies 1 (October): 1-11. 